\title{
Wymywalność zanieczyszczeń z popiołów lotnych ze spalania biomasy
}

\section{Wprowadzenie}

Zwiększenie zainteresowania wykorzystaniem energii ze źródeł odnawialnych spowodowane jest rosnącym - wraz z rozwojem cywilizacyjnym - zapotrzebowaniem na energię.

Szczególną rolę wśród odnawialnych źródeł energii ma biomasa, która jest obecnie coraz szerzej stosowana w energetyce zawodowej (Raport GUS 2014). Najczęściej stosowanym paliwem stałym z biomasy jest biomasa leśna, ale znaczenia nabierają także paliwa z biomasy rolniczej (Fijałkowska i Styszko 2011).

Zużycie biomasy wzrasta zarówno w elektrowniach i elektrociepłowniach stosujących węgiel kamienny jak i brunatny (Emitor 2013). W 2005 roku w elektrowniach i elektrociepłowniach stosujących węgiel brunatny zużycie biomasy wyniosło 660962 GJ, a w 2013 r. wzrosło do 3751 612. Z kolei w 2005 roku w elektrowniach i elektrociepłowniach stosujących węgiel kamienny zużycie biomasy wyniosło 9317763 GJ, a w 2013 r. - 42917011 GJ (Emitor 2013). W zakładach energetyki zawodowej, stosujących jako paliwo podstawowe węgiel kamienny, pozyskanie energii z biomasy było dużo większe niż w tych stosujących węgiel brunatny. W elektrowniach i elektrociepłowniach na biomasę w 2013 r. zużycie tego paliwa wyniosło 26275970 GJ (Emitor 2013).

* Dr hab. inż., prof. AGH, AGH Akademia Górniczo-Hutnicza, Wydział Górnictwa i Geoinżynierii, Kraków; e-mail: aub@agh.edu.pl

** Mgr inż., AGH Akademia Górniczo-Hutnicza, Kraków 
Tak jak podczas spalania węgla kamiennego i brunatnego, tak i podczas spalania biomasy powstają stałe odpady, głównie w postaci popiołów lotnych. Ilość oraz jakość tego typu odpadów zależy przede wszystkim od rodzaju użytej biomasy (Rajamma i in. 2009; Kosior-Kazberuk 2011). Przez odpowiedni dobór biomasy, uwzględniając jej właściwości i skład chemiczny, dla danego typu kotła, można wpłynąć na właściwości popiołów tworzących się podczas spalania (Ściążko i in. 2006), co może decydować o ich ewentualnym wykorzystaniu gospodarczym.

Problemem, w przypadku wykorzystania popiołów ze spalania biomasy, może być wysoka wymywalność niektórych zanieczyszczeń (Vassilev i in. 2013a, b).

W artykule przedstawiono wyniki badań wymywalności zanieczyszczeń z popiołu lotnego ze spalania biomasy i jego zawiesin wodnych w porównaniu do popiołów ze spalania węgla w kotle konwencjonalnym i fluidalnym.

\section{Odpady energetyczne ze spalania biomasy}

Powstające obecnie w wyniku spalania biomasy odpady energetyczne zaliczane są według Rozporządzenia Ministra Środowiska z dnia 9 grudnia 2014 r. w sprawie katalogu odpadów (Dz.U. 2014, poz. 1923) do grupy 10 - odpady z procesów termicznych; podgrupy - 1001 - odpady z elektrowni i innych zakładów energetycznych spalania paliw (z wyłączeniem grupy 19) i są to dwa rodzaje odpadów ze spalania i współspalania: popioły lotne z torfu i drewna niepoddanego obróbce (10 0103 ) oraz popioły paleniskowe oraz popioły lotne ze współspalania inne niż wymienione w 100116 (10 01 17) (Emitor 2013; Uliasz-Bocheńczyk i Mokrzycki 2015).

Oprócz nich katalog wyróżnia jeszcze trzy rodzaje odpadów ze współspalania biomasy:

- 100114 - popioły paleniskowe, żużle i pyły z kotłów ze współspalania zawierające substancje niebezpieczne,

- 100115 - popioły paleniskowe, żużle i pyły z kotłów ze współspalania inne niż wymienione w 1001 14,

- 100116 - popioły lotne ze współspalania zawierające substancje niebezpieczne.

Większość minerałów i faz stwierdzonych w popiołach ze spalania biomasy występuje w popiołach ze spalania węgla, takich jak: krzemiany, tlenki i wodorotlenki, siarczany, fosforany, węglany, chlorki, azotany, krzemionka, kalcyt, anhydryt, peryklaz, hematyt (Vassillev 2013a, b; Jaworek i in. 2013; Giron i in. 2013; Nortey Yeboah i in. 2014). W popiołach lotnych ze spalania biomasy stwierdzono znaczący udział chloru i siarki (Jaworek i in. 2013).

Wykonany przez Vassilev'a i in. (201a, b) przegląd literatury pokazuje, że wymywanie pierwiastków z popiołów ze spalania biomasy można uszeregować w następujący sposób: $\mathrm{Cl}>\mathrm{S}>\mathrm{K}>\mathrm{Na}>\mathrm{Sr}>\mathrm{Ni}>\mathrm{Mn}>\mathrm{Cd}>\mathrm{Kr}>\mathrm{Zn}>\mathrm{Co}>\mathrm{Si}>\mathrm{Mo}>-\mathrm{Li}>(\mathrm{Mg}, \mathrm{Pb})>\mathrm{Ca}$ $>>\mathrm{Cu}>\mathrm{Ba}>\mathrm{P}>\mathrm{Se}>\mathrm{Sb}>\mathrm{Al}>\mathrm{Fe}>(\mathrm{Br}, \mathrm{Hg})>(\mathrm{W}, \mathrm{B}, \mathrm{Sn}, \mathrm{Ti}, \mathrm{V})$, a wysoka wymywalność związana jest $\mathrm{z}$ występowaniem $\mathrm{w}$ tego typu popiołach łatwo rozpuszczalnych chlorków (sylwit, halit), siarczanów (syngenit, ettringit, gips), tlenków $(\mathrm{CaO})$, wodorotlenków 
(portlandyt), azotanów, węglanów i wodorowęglanów. Wysoka wymywalność zanieczyszczeń, takich jak: $\mathrm{Ba}, \mathrm{Cl}, \mathrm{Cr}, \mathrm{Mo}, \mathrm{Pb}$ może stanowić problem środowiskowy (Vassilev i in. 2013a, b). Może to również ograniczyć możliwość gospodarczego wykorzystania popiołów ze spalania biomasy w górnictwie, które jest największym odbiorcą popiołów lotnych w Polsce (Emitor 2013).

\section{Materiały wykorzystane do badań}

Badania przeprowadzono na trzech rodzajach popiołów (rys. 1):

- ze spalania węgla kamiennego w kotle konwencjonalnym (10 0102$)$ PK - rysunek 1c,

- z kotłów fluidalnych ze spalania węgla kamiennego (10 01 82) PF - rysunek 1a,

- ze spalania biomasy (10 0103$)$ PB - rysunek 1b

o składach chemicznych przedstawionych w tabeli 1 i parametrach fizycznych przedstawionych w tabeli 2 .

a)

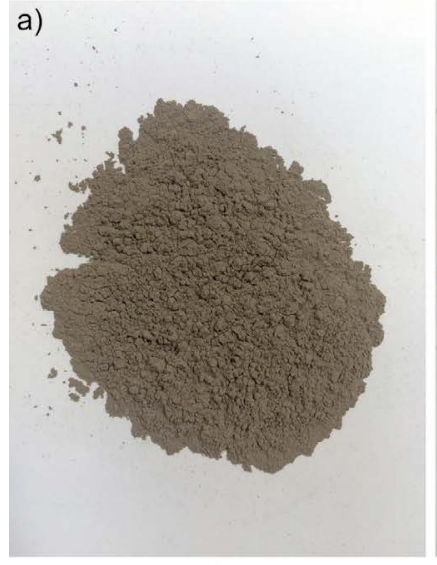

PF

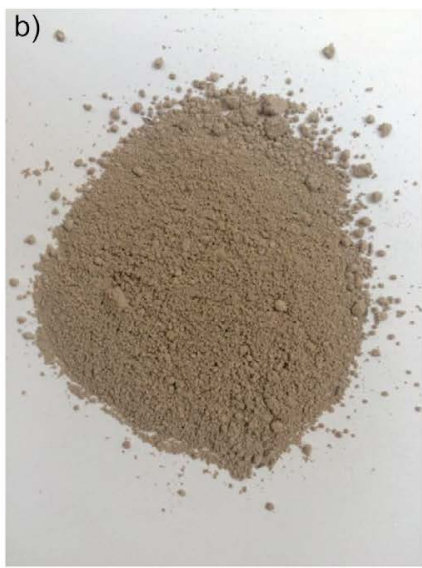

PB

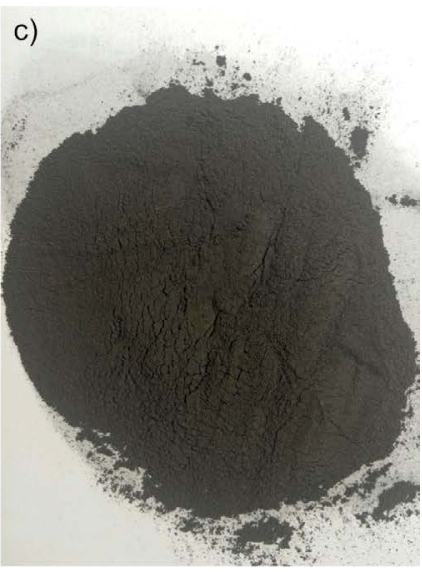

PK

Rys. 1. Próbki badanych popiołów

Fig. 1. Samples of tested ash

Popioły lotne ze spalania biomasy, w porównaniu z popiołami ze spalania węgla kamiennego, charakteryzują się wysoką zawartością $\mathrm{CaO}, \mathrm{SO}_{3}$ i Cl. Zawartość $\mathrm{SiO}_{2}, \mathrm{Al}_{2} \mathrm{O}_{3}$ i $\mathrm{Fe}_{2} \mathrm{O}_{3}$ jest $\mathrm{w}$ tych popiołach niższa od tych ze spalania węgla. Uzyskane wyniki potwierdzają badania innych autorów (Girón i in. 2013; Hinojosa i in. 2014; Nortey Yeboah i in. 2014; Rajamma i in. 2009) (tab. 1).

Według normy BN-79/6732.09 analizowane popioły ze spalania węgla w kotłach zarówno fluidalnych jaki i konwencjonalnych można zaliczyć do popiołów krzemiokowych. Popioły ze spalania biomasy nie mieszczą się w klasyfikacji niniejszej normy. 
Straty prażnia popiołów ze spalania biomasy są wyższe od tych ze spalania węgla w kotłach fluidalnych i niższe od tych charakteryzujących popioły z kotłów konwencjonalnych (tab. 1).

Popioły ze spalania biomasy charakteryzują się najwyższą gęstością, najwyższym stopniem porowatości oraz największą powierzchnią właściwą spośród badanych odpadów (tab. 2).

Tabela 1. Skład chemiczny popiołów zastosowanych do badań [\%]

Table 1. Chemical composition of ash used for researches [\%]

\begin{tabular}{|c|c|c|c|}
\hline \multirow{2}{*}{ Składnik } & \multicolumn{3}{|c|}{ Rodzaj popiołu } \\
\cline { 2 - 4 } & 100102 & 100182 & 100103 \\
\hline $\mathrm{Na}_{2} \mathrm{O}$ & 0,7705 & 0,9035 & 0,4858 \\
\hline $\mathrm{K}_{2} \mathrm{O}$ & 1,1738 & 1,5850 & 31,0593 \\
\hline $\mathrm{CaO}$ & 4,0988 & 4,2503 & 14,4716 \\
\hline $\mathrm{MgO}$ & 2,9060 & 3,0280 & 5,2879 \\
\hline $\mathrm{SO}_{3}$ & 0,6356 & 0,7559 & 17,9606 \\
\hline $\mathrm{Al}_{2} \mathrm{O}_{3}$ & 8,8938 & 11,2743 & 1,5357 \\
\hline $\mathrm{Fe}_{2} \mathrm{O}_{3}$ & 6,1752 & 5,6252 & 1,9666 \\
\hline $\mathrm{SiO}_{2}$ & 42,5000 & 51,2000 & 16,8000 \\
\hline $\mathrm{Cl}^{2}$ & b.d. & b.d. & 1,19248 \\
\hline Straty prażenia & 1,69 & 0,11 & 0,27 \\
\hline
\end{tabular}

Tabela 2. Parametry fizyczne badanych popiołów lotnych

Table 2. Physical parameters of the tested fly ash

\begin{tabular}{|c|c|c|c|c|c|}
\hline $\begin{array}{c}\text { Rodzaj } \\
\text { popiołu }\end{array}$ & $\begin{array}{c}\text { Wilgotność } \\
{[\%]}\end{array}$ & $\begin{array}{c}\text { Gęstość } \\
\text { właściwa } \\
{\left[\mathrm{kg} / \mathrm{m}^{3}\right]}\end{array}$ & $\begin{array}{c}\text { Gęstość } \\
\text { nasypowa } \\
{\left[\mathrm{kg} / \mathrm{m}^{3}\right]}\end{array}$ & $\begin{array}{c}\text { Stopień } \\
\text { porowatości } \\
{[\%]}\end{array}$ & $\begin{array}{c}\text { Powierzchnia } \\
\text { właściwa } \\
{\left[\mathrm{cm}^{2} / \mathrm{g}\right]}\end{array}$ \\
\hline $\mathrm{PK}$ & 1,032 & 1,98 & 0,4818 & 75,67 & 5757,39 \\
\hline $\mathrm{PB}$ & 0,969 & 2,83 & 0,4511 & 84,06 & 8474,66 \\
\hline $\mathrm{PF}$ & 0,433 & 2,26 & 0,4467 & 80,23 & 5172,92 \\
\hline
\end{tabular}

\section{Wyniki badań - wymywalność zanieczyszczeń}

Badania przeprowadzono według zaleceń zawartych w normie - PN-G-11011 Górnictwo - Materiały do podsadzki zestalanej i doszczelniania zrobów - Wymagania i badania. Wyniki badań zestawiono w tabelach 3 i 4. Badania wymywalności porównano z dopuszczalnymi wielkościami wymywalności zawartymi w normach - PN-G-11011. 


\begin{tabular}{|c|c|c|c|c|c|c|c|c|c|c|c|c|c|c|c|}
\hline & 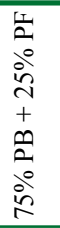 & $\tilde{a}$ & & $\begin{array}{l}\hat{n} \\
\hat{n}\end{array}$ & $\begin{array}{l}8 \\
\text { in } \\
\text { in }\end{array}$ & $\begin{array}{l}\circ \\
\stackrel{0}{\circ} \\
\circ\end{array}$ & 容 & \begin{tabular}{l} 
ôे \\
\multirow{0}{0}{} \\
0
\end{tabular} & 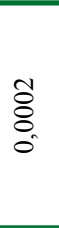 & $\begin{array}{l}\text { तิ } \\
\text { ठ̊. } \\
\text { o. }\end{array}$ & 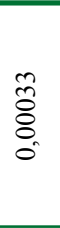 & 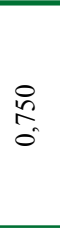 & $\begin{array}{l}8 \\
\stackrel{0}{0} \\
\stackrel{0}{0}\end{array}$ & $\begin{array}{l}0 \\
\stackrel{0}{0} \\
\stackrel{-}{-}\end{array}$ & $\begin{array}{l}8 \\
i \\
i n \\
m\end{array}$ \\
\hline & 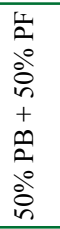 & $\begin{array}{l}\infty \\
\infty \\
\simeq \\
\simeq\end{array}$ & & $\begin{array}{l}\stackrel{2}{0} \\
\stackrel{6}{=}\end{array}$ & $\begin{array}{l}8 \\
\hat{i} \\
\text { है } \\
a\end{array}$ & $\begin{array}{l}\stackrel{0}{8} \\
\stackrel{0}{\circ}\end{array}$ & $\begin{array}{l}8 \\
0 \\
0 \\
0\end{array}$ & $\begin{array}{l}\stackrel{\AA}{ } \\
\text { ठे. } \\
\text { ठ }\end{array}$ & $\begin{array}{l}\frac{1}{0} \\
0 \\
0\end{array}$ & 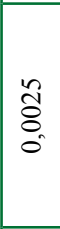 & $\begin{array}{l}\hat{\sigma} \\
\hat{o} \\
0 \\
0\end{array}$ & \begin{tabular}{l}
$\infty$ \\
\multirow{0}{0}{} \\
0 \\
0
\end{tabular} & $\begin{array}{l}0 \\
\\
0 \\
0\end{array}$ & 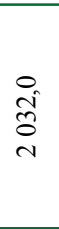 & $\begin{array}{l}\stackrel{8}{0} \\
\stackrel{+}{\sim}\end{array}$ \\
\hline & 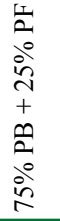 & $\stackrel{n}{\cong}$ & & 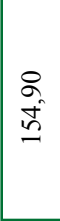 & $\begin{array}{l}8 \\
8 \\
0 \\
0 \\
0\end{array}$ & $\begin{array}{l}\circ \\
\stackrel{8}{\circ}\end{array}$ & $\begin{array}{l}2 \\
\vdots \\
0 \\
0\end{array}$ & 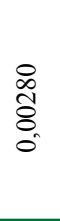 & $\begin{array}{l}0 \\
0 \\
0 \\
0 \\
0\end{array}$ & 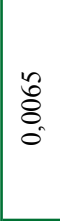 & $\begin{array}{l}\stackrel{0}{m} \\
\frac{m}{8} \\
0\end{array}$ & $\stackrel{\hat{o}}{-}$ & $\begin{array}{l}\stackrel{0}{\vec{d}} \\
\stackrel{0}{0}\end{array}$ & $\begin{array}{l}\stackrel{0}{\text { I }} \\
\text { aे }\end{array}$ & $\begin{array}{l}8 \\
: \\
8 \\
0 \\
0\end{array}$ \\
\hline & 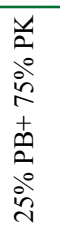 & $\begin{array}{l}\text { ले } \\
\stackrel{=}{=}\end{array}$ & & $\begin{array}{l}\vec{\gamma} \\
\hat{n}\end{array}$ & $\begin{array}{l}8 \\
0 \\
0 \\
0 \\
i\end{array}$ & $\begin{array}{l}\stackrel{\circ}{8} \\
\stackrel{0}{\circ}\end{array}$ & $\vec{\sigma}$ & $\begin{array}{l}\stackrel{0}{0} \\
\stackrel{0}{0} \\
\dot{0}\end{array}$ & $\bar{\delta}$ & \begin{tabular}{|l}
$\infty$ \\
ర్ \\
. \\
0
\end{tabular} & $\begin{array}{l}\infty \\
\widetilde{0} \\
\tilde{o}_{0} \\
0\end{array}$ & 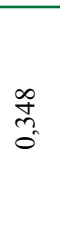 & $\begin{array}{l}0 \\
0 \\
0 \\
0 \\
0\end{array}$ & $\begin{array}{l}0 \\
\text { को } \\
\stackrel{0}{n}\end{array}$ & \begin{tabular}{l}
8 \\
$\stackrel{r}{\kappa}$ \\
\multirow{\sigma}{*}{}
\end{tabular} \\
\hline 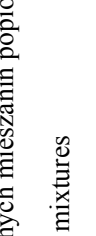 & 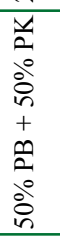 & $\begin{array}{l}\infty \\
\stackrel{\infty}{\simeq} \\
\stackrel{]}{\simeq}\end{array}$ & 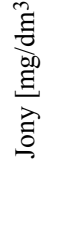 & $\begin{array}{l}0 \\
\hat{2} \\
0 \\
0\end{array}$ & $\begin{array}{l}8 \\
\circ \\
\stackrel{0}{0} \\
0\end{array}$ & $\begin{array}{l}\stackrel{0}{8} \\
\stackrel{0}{\circ}\end{array}$ & \begin{tabular}{l}
0 \\
\multirow{0}{0}{} \\
0
\end{tabular} & $\begin{array}{l}\frac{i}{n} \\
\frac{0}{8} \\
0\end{array}$ & 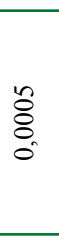 & $\begin{array}{l}0 \\
0 \\
0 \\
0\end{array}$ & $\begin{array}{l}\overrightarrow{0} \\
\stackrel{0}{0} \\
0\end{array}$ & $\begin{array}{l}n \\
0 \\
0 \\
0 \\
0\end{array}$ & $\begin{array}{l}\frac{0}{3} \\
\hat{0} \\
0\end{array}$ & $\begin{array}{l}0 \\
\infty \\
\stackrel{0}{0} \\
\stackrel{N}{N}\end{array}$ & $\begin{array}{l}8 \\
\stackrel{n}{N} \\
a\end{array}$ \\
\hline 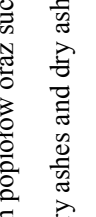 & 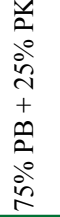 & $\begin{array}{l}\text { f } \\
\text { I }\end{array}$ & & $\begin{array}{l}8 \\
0 \\
0 \\
0\end{array}$ & $\begin{array}{l}8 \\
8 \\
0 \\
-1\end{array}$ & $\begin{array}{l}0 \\
\stackrel{0}{0}\end{array}$ & 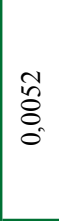 & $\frac{8}{8}$ & $\vec{\circ}$ & 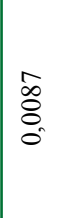 & 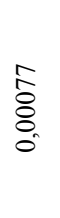 & م् & 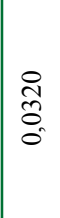 & $\begin{array}{l}\stackrel{i}{0} \\
\stackrel{0}{m}\end{array}$ & $\begin{array}{l}8 \\
: \\
0 \\
\text { In }\end{array}$ \\
\hline 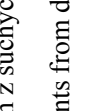 & $\stackrel{I I}{a}$ & $\begin{array}{l}\hat{\sigma} \\
=\end{array}$ & & $\begin{array}{l}\vec{b} \\
\text { d } \\
\tilde{n}\end{array}$ & $\begin{array}{l}\vec{त} \\
\text { do } \\
\stackrel{\sim}{0}\end{array}$ & $\begin{array}{l}\stackrel{0}{8} \\
\stackrel{0}{0}\end{array}$ & $\bar{\Xi}$ & $\begin{array}{l}\stackrel{8}{1} \\
\text { ठิ. } \\
0\end{array}$ & ठे & $\frac{n}{8}$ & $\begin{array}{l}\text { in } \\
\text { ò } \\
0\end{array}$ & $\stackrel{\tilde{\partial}}{0}$ & 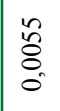 & $\begin{array}{l}\stackrel{2}{o} \\
\stackrel{a}{a}\end{array}$ & 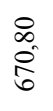 \\
\hline 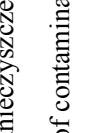 & $\stackrel{m}{a}$ & $\begin{array}{l}\hat{\Omega} \\
\text { I }\end{array}$ & & $\begin{array}{l}8 \\
8 \\
0 \\
\\
\end{array}$ & $\begin{array}{l}\stackrel{0}{0} \\
0 \\
0 \\
0\end{array}$ & $\begin{array}{l}\circ \\
\stackrel{8}{8} \\
0\end{array}$ & 足 & $\begin{array}{l}8 \\
\stackrel{0}{0} \\
\stackrel{0}{0} \\
0\end{array}$ & $\overline{8}$ & $\begin{array}{l}0 \\
0 \\
o \\
0 \\
0\end{array}$ & $\begin{array}{l}\stackrel{0}{0} \\
8 \\
0 \\
0\end{array}$ & $\begin{array}{l}0 \\
\text { on } \\
\text { in }\end{array}$ & \begin{tabular}{l}
0 \\
\multirow{y}{0}{} \\
0 \\
0
\end{tabular} & $\begin{array}{l}\text { ते } \\
\text { o } \\
\text { n }\end{array}$ & $\begin{array}{l}8 \\
0 \\
\infty \\
0 \\
0\end{array}$ \\
\hline 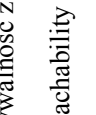 & $\frac{v}{a}$ & $\begin{array}{l}\tilde{\Xi} \\
\tilde{\Xi}\end{array}$ & & $\begin{array}{l}F \\
\dot{\exists}\end{array}$ & fo & $\begin{array}{l}\circ \\
\stackrel{0}{8} \\
0\end{array}$ & $\overline{\grave{o}}$ & $\begin{array}{l}\infty \\
\stackrel{0}{8} \\
0\end{array}$ & $\begin{array}{l}\vec{n} \\
\dot{0} \\
0\end{array}$ & 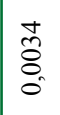 & $\begin{array}{l}\infty \\
\stackrel{\infty}{\Xi} \\
\stackrel{0}{0}\end{array}$ & 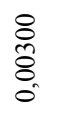 & 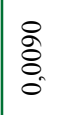 & $\begin{array}{l}0 \\
\vec{m}\end{array}$ & 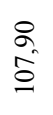 \\
\hline$\frac{\dot{m}}{0}$ & 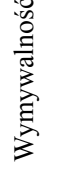 & $\stackrel{T}{2}$ & & $\ddot{z}$ & 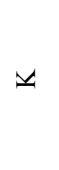 & งี & $\bar{J}$ & $\bar{z}$ & $\overrightarrow{2}$ & $\underbrace{\infty}$ & $\bar{U}$ & $\dot{U}$ & 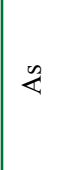 & $\bar{U}$ & $\overbrace{\mathscr{C}}^{+}$ \\
\hline
\end{tabular}




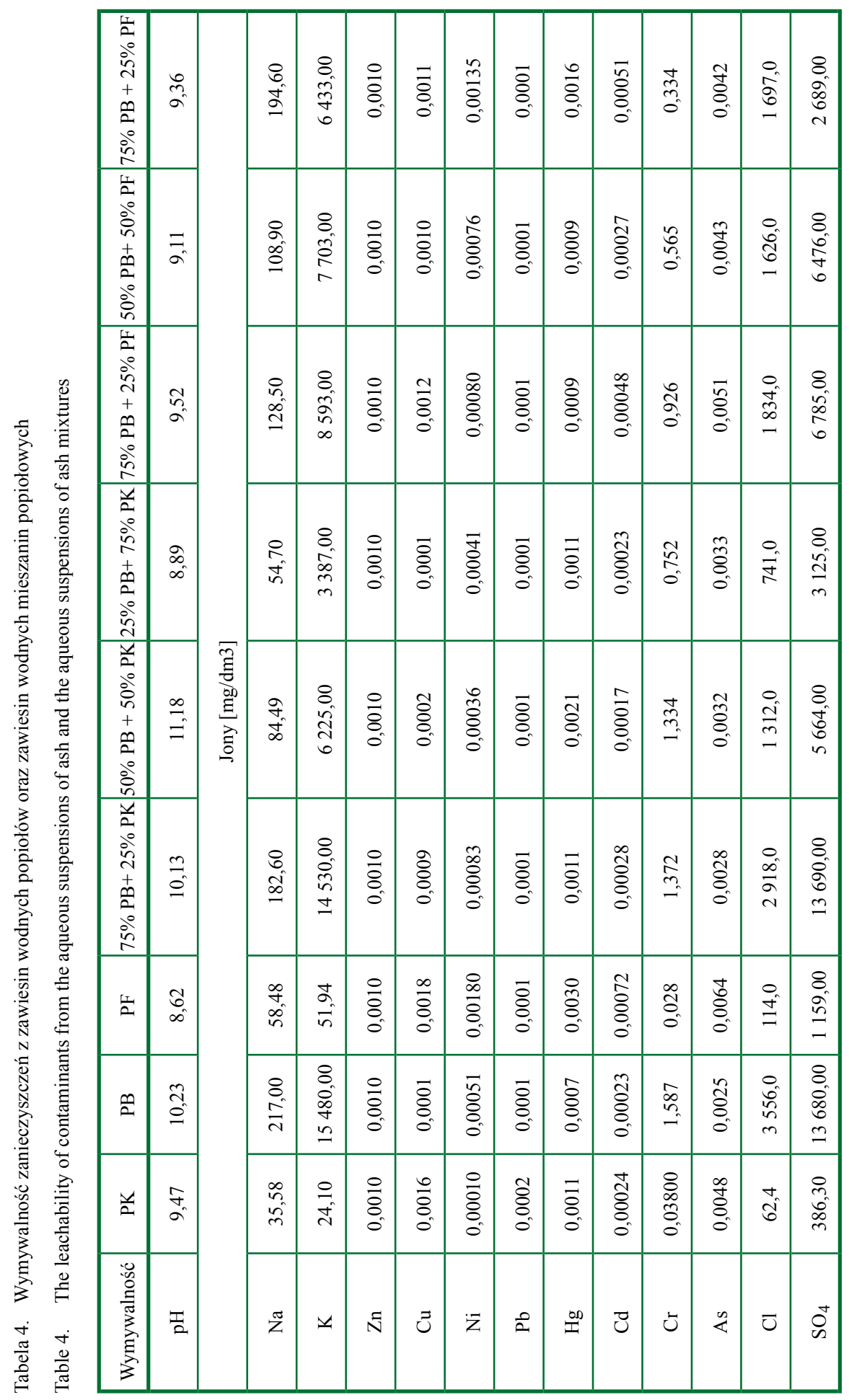


Badania wymywalności przeprowadzono dla następujących zestawów próbek popiołów suchych oraz zawiesin wodnych:

- $100 \% \mathrm{PK}$,

$100 \% \mathrm{PK}$,

$100 \% \mathrm{PF}$,

$75 \% \mathrm{~PB}+25 \% \mathrm{PK}$,

$50 \% \mathrm{~PB}+50 \% \mathrm{PK}$,

- $25 \% \mathrm{~PB}+75 \% \mathrm{PK}$,

$75 \% \mathrm{~PB}+25 \% \mathrm{PF}$,

- $50 \% \mathrm{~PB}+50 \% \mathrm{PF}$

- $25 \% \mathrm{~PB}+75 \% \mathrm{PF}$.

Zawiesiny wykonano przy stosunku popiołu do wody wynoszącym 0,7 .

Analizowane próbki wszystkich trzech popiołów charakteryzowały się porównywalnym pH w zakresie od 11,92 do 12,85.

Przeprowadzone badania wykazały bardzo wysoką wymywalność jonów potasu z popiołów ze spalania biomasy $(100103)\left(19080 \mathrm{mg} / \mathrm{dm}^{3}\right)$ w porównaniu z popiołami ze spalania węgla kamiennego $(100102)\left(6,46 \mathrm{mg} / \mathrm{dm}^{3}\right)$ oraz ze spalania węgla kamiennego w kotłach fluidalnych $\left(\begin{array}{lll}10 & 01 & 82\end{array}\right)\left(28,21 \mathrm{mg} / \mathrm{dm}^{3}\right)$. Popioły te charakteryzowały się również znaczącą wymywalnością chromu $1,587 \mathrm{mg} / \mathrm{dm}^{3}$, w porównaniu z popiołami ze spalania węgla, które charakteryzowały się odpowiednio wymywalnością 0,003 i $0,017 \mathrm{mg} / \mathrm{dm}^{3}$ (tab. 3).

Wysoka wymywalność zanieczyszczeń związana jest ze składem chemicznym i fazowym badanych popiołów. Obecność chloru i $\mathrm{SO}_{3}$ w popiołach, w formach najprawdopodobniej łatwo rozpuszczalnych, skutkuje wysokim stężeniem tych jonów w odciekach.

Wymywalnośc chlorków $\left(3829,0 \mathrm{mg} / \mathrm{dm}^{3}\right)$ również jest o rzędy wielkości wyższa od tych stwierdzonych dla popiołów ze spalania węgla (odpowiednio: 37,6 i $109,2 \mathrm{mg} / \mathrm{dm}^{3}$ ) (tab. 3).

Zanieczyszczeniem, którego wysoka wymywalność zwraca również uwagę w prezentowanych wynikach są siarczany, których wartość dla popiołów z biomasy wynosi $16980 \mathrm{mg} / \mathrm{dm}^{3}$. Wysoka wymywalność siarczanów, chloru i potasu potwierdza wyniki badań otrzymane przez innych autorów (Jaworek i in. 2013; Vassilev 2013a, b). Uzyskane wartości wymywalności dla popiołów ze spalania biomasy znacznie przekraczały wymagania zawarte w tabeli 5 .

Wykonanie suchych mieszanek z popiołami PK oraz PF pozwoliło na obniżenie wymywalności potasu, chromu siarczanów i chlorków proporcjonalnie do zawartości popiołów $\mathrm{z}$ biomasy, jednak na poziomie nie spełniającym wymagań normowych (tab. 5).

Zawiesiny wodne popiołów ze spalania biomasy - pomimo obniżenia wymywalności w porównaniu z suchymi popiołami - wykazywały znaczne wymywalności tych samych problematycznych w tym przypadku - jonów potasu, chromu, siarczanów i chlorków (tab. 4). Przekraczając tym samym znacznie wymagania normy PN-G-11011.

Zawiesiny wodne mieszanek z popiołami PK oraz PF również charakteryzowały się niższą wymywalnością problematycznych jonów w stosunku do zawiesiny wodnej popio- 
Tabela 5. Dopuszczalne wielkości wymywalności zawarte w normie - PN-G-11011

Table 5. Permissible leachability values according to the PN-G-11011 standard

\begin{tabular}{|c|c|}
\hline Rodzaj zanieczyszczeń chemicznych & $\begin{array}{c}\text { Dopuszczalne wielkości wymywalności } \\
\text { zawarte w normie - PN-G-11011 }\end{array}$ \\
\hline Pierwiastki $\left[\mathrm{mg} / \mathrm{dm}^{3}\right]$ & 2,0 \\
\hline$\bullet$ Cynk $(\mathrm{Zn})$ & 0,5 \\
\hline$\bullet$ Miedź $(\mathrm{Cu})$ & 0,5 \\
\hline$\bullet$ Ołów $(\mathrm{Pb})$ & - \\
\hline$\bullet$ Nikiel $(\mathrm{Ni})$ & 0,2 \\
\hline$\bullet$ Arsen $(\mathrm{As})$ & 0,02 \\
\hline$\bullet$ Rtęć $(\mathrm{Hg})$ & 0,1 \\
\hline$\bullet$ Kadm $(\mathrm{Cd})$ & 0,5 \\
\hline$\bullet$ Chrom $(\mathrm{Cr})$ & 1000,0 \\
\hline Chlorki $\left(\mathrm{Cl}^{-}\right)\left[\mathrm{mg} / \mathrm{dm}^{3}\right]$ & 500,0 \\
\hline Siarczany $\left(\mathrm{SO}{ }^{2-}\right)\left[\mathrm{mg}^{2} / \mathrm{dm}^{3}\right]$ & $6,0-12,0$ \\
\hline pH & \\
\hline
\end{tabular}

Tabela 6. Właściwości świeżych zawiesin popiołowo-wodnych

Table 6. The properties of fresh ash-water suspensions

\begin{tabular}{|c|c|c|c|c|c|}
\hline \multirow{2}{*}{ Zawiesina } & \multirow{2}{*}{$\begin{array}{c}\text { Rozlewność } \\
{[\mathrm{mm}]}\end{array}$} & \multirow{2}{*}{$\begin{array}{c}\text { Gęstość } \\
\text { zawiesiny } \\
{\left[\mathrm{g} / \mathrm{cm}^{3}\right]}\end{array}$} & \multirow{2}{*}{$\begin{array}{c}\text { Ilość wody } \\
\text { nadosadowej } \\
{[\%]}\end{array}$} & \multicolumn{2}{|c|}{ Czas wiązania [doba] } \\
\hline & & & & początek & koniec \\
\hline $\mathrm{PB}$ & 180 & 1,31 & 11,85 & 12 & 16 \\
\hline PK & 210 & 1,22 & 9,30 & 3 & 7 \\
\hline $\mathrm{PF}$ & 200 & 1,28 & 3,22 & 5 & 11 \\
\hline $75 \% \mathrm{~PB}+25 \% \mathrm{PK}$ & 180 & 1,3 & 8,43 & 12 & 16 \\
\hline $50 \% \mathrm{~PB}+50 \% \mathrm{PK}$ & 180 & 1,29 & 8,55 & 11 & 16 \\
\hline $25 \% \mathrm{~PB}+75 \% \mathrm{PK}$ & 210 & 1,25 & 8,78 & 5 & 9 \\
\hline $75 \% \mathrm{~PB}+25 \% \mathrm{PF}$ & 200 & 1,32 & 2,01 & 12 & 17 \\
\hline $50 \% \mathrm{~PB}+50 \% \mathrm{PF}$ & 200 & 1,31 & 1,00 & 10 & 17 \\
\hline $25 \% \mathrm{~PB}+75 \% \mathrm{PF}$ & 190 & 1,28 & 0,00 & 6,5 & 13 \\
\hline
\end{tabular}


łów $\mathrm{PB}$, jednak na poziomie przekraczającym wymagania zawarte w tabeli 6 , $\mathrm{z}$ wyjątkiem mieszaniny o składzie: $25 \%$ PB $+75 \%$ PF, której wymywalność chromu i chlorków spełnia normę górniczą. Problematyczna pozostaje jednak wysoka zawartość siarczanów. Uzyskane obniżenie wymywalności było najprawdopodobniej spowodowane utworzeniem uwodnionych krzemianów wapniowych oraz ettryngitu (Deja 2002).

Wykonane dla określenia wymywalności zanieczyszczeń zawiesiny wodne popiołów poddano również oznaczeniu podstawowych właściwości, takich jak: rozlewność, gęstość, ilość wody nadosadowej i czas wiązania (tab. 6).

Pomiar rozlewności wykonano według normy PN-85/G-02320 - Wiertnictwo. Cementy i zaczyny cementowe do cementowania w otworach wiertniczych, przy wykorzystaniu stożka typu AzNII.

Oznaczenie czasu wiązania zostało przeprowadzone według PN-EN 196-3:1996 - Oznaczanie czasów wiązania i stałości objętości, aparatem Vicata.

Ilość wody nadosadowej została oznaczona według normy PN-G-11011 - Materiały do podsadzki zestalonej i doszczelniania zrobów.

Najniższą (180 mm) rozlewność stwierdzono dla zawiesin wodnych popiołów ze spalania biomasy i mieszanin o składach: $75 \%$ PB + 25\% PK i 50\% PB + 50\% PK, a najwyższą charakteryzowała się zawiesina wodna popiołu ze spalania węgla w kotle fluidalnym (PF) oraz zawiesiny mieszanin: $25 \% \mathrm{~PB}+75 \% \mathrm{PK}$. Dla zawiesin wodnych popiołów ze spalania biomasy stwierdzono najdłuższy czas wiązania, tak jak dla tych sporządzonych z maksymalną zawartością tych odpadów. Również odstój zawiesin popiołów ze spalania biomasy był najwyższy. Analizowane zawiesiny charakteryzowały się porównywalną gęstością w granicach od 1,22 do $1,32 \mathrm{~g} / \mathrm{cm}^{3}$.

\section{Podsumowanie}

Przedstawione wyniki są badaniami wstępnymi, w programie mającym na celu ograniczenie wymywalności zanieczyszczeń z popiołów ze spalania biomasy.

Analizowane popioły lotne ze spalania węgla kamiennego w kotłach fluidalnych, w kotłach konwencjonalnych oraz biomasy różnią się znacząco ilościowo składem chemicznym. Na szczególną uwagę w popiołach ze spalania biomasy zwraca obecność chloru, której nie stwierdzono w popiołach ze spalania węgla oraz wysoka zawartość $\mathrm{SO}_{3}$. Popioły te charakteryzują się podobnymi właściwościami fizycznymi.

Badane popioły charakteryzowały się wysoką wymywalnością jonów siarczanowych, chlorków, potasu i chromu, w ilościach znacznie przewyższających wartości uzyskane dla popiołów ze spalania węgla w kotłach konwencjonalnych i fluidalnych.

Wysoka wymywalność zanieczyszczeń z popiołów ze spalania biomasy, związana przede wszystkim z rodzajem paliwa, może być w najprostszy sposób ograniczona przez zmieszanie ich z popiołami ze spalania węgla z kotłów konwencjonalnych i kotłów fluidalnych. Również sporządzenie wodnych zawiesin popiołów pozwala na obniżenie wymywal- 
ności. Jednak pomimo redukcji, wartości wymywalności znacznie przekraczają wymagania normy PN-G-11011 Materiały do podsadzki zestalanej i doszczelniania zrobów zawałowych. Wymagania i badania.

Artykut opracowano w ramach badań statutowych AGH nr 11.11.100.482.

\section{LITERATURA}

Deja 2002. Immobilization of $\mathrm{Cr}^{6+}, \mathrm{Cd}^{2+}, \mathrm{Zn}^{2+}$ and $\mathrm{Pb}^{2+}$ in alkali-activated slag binders. Cement and Concrete Research 32, s. 1971-1979.

Emitor 2013. Emisja zanieczyszczeń środowiska w elektrowniach i elektrociepłowniach zawodowych. Agencja Rynku Energii, Warszawa.

Fijałkowska, D. i Styszko, L. 2011. Ciepło spalania biomasy wierzbowej. Rocznik Ochrona Środowiska 13, s. $875--890$

Girón i in. 2013 - Girón, R.P., Ruiz, B., Fuente, E., Gil, R.R. i Suárez-Ruiz, I. 2013. Properties of fly ash from forest biomass combustion. Fuel 114, s. 71-77.

Hinojosa i in. 2014 - Hinojosa, M., Galvín, A., Agrela, F., Perianes, M. i Barbudo, A. 2014. Potential use of biomass bottom ash as alternative construction material: Conflictive chemical parameters according to technical regulations. Fuel 128, s. 248-259.

Jaworek i in. 2013 - Jaworek, A., Czech, T., Sobczyk, A.T. i Krupa, A. 2013. Properties of biomass vs. coal fly ashes deposited in electrostatic precipitator. Journal of Electrostatics 71, s. 165-175.

Kosior-Kazberuk, M. 2011. Nowe dodatki mineralne do betonu, Budownictwo i inżynieria środowiska. s. 2081-3279.

Nortey Yeboah i in. 2014 - Nortey Yeboah, N.N., Shearer, Ch.R., Burns, S.E. i Kurtis, Kimberly, E. 2014. Characterization of biomass and high carbon content coal ash for productive reuse applications. Fuel 116, s. 438-447.

Rajamma i in. 2009 - Rajamma, R., Ball, R., Tarelho, L.., Allen, G., Labrincha, J. i Ferreira, V. 2009. Characterisation and use of biomass fly ash in cement-based materials. Journal of Hazardous Materials 172, s. 1049-1060

Raport GUS 2014. Energia ze źródeł odnawialnych w 2013 r. Główny Urząd Statystyczny. Warszawa, $72 \mathrm{~s}$.

Ściążko i in. 2006 - Ściążko, M., Zuwała, J. i Pronobis, M. 2006. Zalety i wady współspalania biomasy w kotłach energetycznych na tle doświadczeń eksploatacyjnych pierwszego roku współspalania biomasy na skalę przemysłową. Energetyka 3, s. 207-220.

Uliasz-Bocheńczyk, A. i Mokrzycki, E., 2015. Biomasa jako paliwo w energetyce. Rocznik Ochrona Środowiska 17, s. 900-913.

Vassilev 2013a - Vassilev, S., Baxter, D., Andersen, L. i Vassileva, C. 2013a. An overview of the composition and application of biomass ash. Part 1.Phase-mineral and chemical composition and classification. Fuel 105, s. $40-76$.

Vassilev 2013b - Vassilev, S., Baxter, D., Andersen, L. i Vassileva, C. 2013b. An overview of the composition and application of biomass ash. Part 2. Potential utilisation, technological and ecological advantages and challenges. Fuel 105, s. 19-39. 
WYMYWALNOŚĆ ZANIECZYSZCZEŃ Z POPIOŁÓW LOTNYCH ZE SPALANIA BIOMASY

\author{
Słowa kluczowe
}

odpady energetyczne, popioły ze spalania biomasy, wymywalność zanieczyszczeń

\title{
Streszczenie
}

Biomasa stanowi obecnie jedno z podstawowych źródeł energii odnawialnej w energetyce zawodowej w Polsce. Wykorzystanie tego paliwa wynika z obowiązującej Polityki Energetycznej Polski do 2030, która narzuca wzrost udziału odnawialnych źródeł energii w finalnym zużyciu energii co najmniej do poziomu 15\% w 2020 roku, a następnie dalszy wzrost w latach następnych. Projekt Polityki energetycznej Polski do 2050 roku zakłada zwiększenie do $20 \%$ udziału energii odnawialnej we wszystkich źródłach zużywanej energii. Biomasa może być stosowana jako samodzielne paliwo lub może być współspalana z węglem. Każde paliwo stałe, również biomasa, w energetyce zawodowej powoduje powstawanie odpadów energetycznych. W przypadku każdego odpadu powinna być zachowana hierarchia sposobów postępowania z nimi zdefiniowana w Ustawie o odpadach. Odpady energetyczne są szeroko wykorzystywane w górnictwie, produkcji materiałów budowlanych i drogownictwie. Również dla ubocznych produktów spalania biomasy są to kierunki, które powinny być rozpatrywane w pierwszej kolejności ze względu na długoletnie doświadczenia w ich wykorzystaniu. Przykładowo, popioły lotne ze współspalania są dopuszczone przez normę PN-EN 450:1 - Popiół lotny do betonu. Popioły lotne ze spalania biomasy różnią się, pomimo wielu podobieństw, od popiołów ze spalania węgla czy współspalania. Popioły te mogą charakteryzować się wysoką wymywalnością zanieczyszczeń i przez to ich gospodarcze wykorzystanie może być ograniczone. W artykule przedstawiono wyniki badań wymywalności zanieczyszczeń z suchych popiołów lotnych i ich wodnych zawiesin. Dla porównania wykonano oznaczenie wymywalności zanieczyszczeń z popiołów ze spalania węgla w kotłach konwencjonalnych i kotłach fluidalnych. Badane popioły ze spalania biomasy charakteryzowały się wysoką wymywalnością siarczanów, chlorków, chromu i potasu. Ponieważ górnictwo podziemne pozostaje jednym z podstawowych kierunków wykorzystania popiołów lotnych, uzyskane wyniki badań porównano z wymaganiami normy PN-G-11011 - Materiały do podsadzki zestalanej i doszczelniania zrobów zawałowych. Wymagania i badania.

\section{LEACHING OF POLLUTANTS FROM FLY ASH FROM THE COMBUSTION OF BIOMASS}

$$
\text { Keywords }
$$

energetic waste, ash from the biomass combustion, leachability of contaminants

$$
\text { Abstract }
$$

The biomass is currently one of the main renewable energy sources in the Polish power industry. The use of this fuel results from the current Polish Energy Policy until 2030, which imposes an incre- 
ase in the share of renewables in final energy consumption to a minimum of $15 \%$ by 2020 and a further increase in the subsquent years. The Polish Energy Policy until 2050 assumes that share of renewables in all energy sources will increase to $20 \%$. The biomass can be used as a standalone fuel or can be co-fired with coal. However, as with any solid fuel, the use of biomass in the power industry also generates waste. As with any waste, specific rules on waste management should be defined in the Act on Waste. Energetic waste is widely used in mining, building materials and road construction. Given the long experience in their use, the use of biomass combustion by-products should also be considered. This takes place in the case of fly ashes from co-combustion, which are, for example, compliant with the PN-EN 450: 1 standard "Fly ash for concrete". Fly ash from biomass combustion is different, despite many similarities, from the ashes resulting from coal combustion and co-combustion. The ashes can be characterized by a high leachability of contaminants and thus their economic use may be restricted. The paper presents results of research on the leachability of contaminants from dry fly ashes and their aqueous suspensions. For purposes of comparison, the leachability of contaminants from ashes resulting from the combustion of coal in both conventional and fluidized bed boilers has been determined. The tested ashes from biomass combustion were characterized by a high leachability of sulphates, chlorides, chromium and potassium. Since underground mining remains one of the main directions of the use of fly ash, the obtained results were compared with the PN-G-11011 standard "The materials for solidifying backfill and gob grouting; Requirements and testing, Requirements and testing". 